\title{
溶融スラグによる溶銅中の $\mathrm{Pb}$ の酸化除去速度*
}

\author{
山本 恵 介 $^{1}$ 柴 田 悦 郎 $^{2}$ 田堀 裕 $3^{3}$ \\ 中島 邦 彦 4 森 克 $\mathrm{E}^{5}$
}

\section{Oxidation Rate of Lead in Liquid Copper by Molten Slags}

by Keisuke YAMAMOTO ${ }^{1}$, Etsuro SHIBATA ${ }^{2}$, Hiroko TAHORI ${ }^{3}$, Kunihiko NAKASHIMA ${ }^{3}$ and Katsumi MORI ${ }^{3}$

1. Graduate student, Graduate School of Kyushu University (present : Sumitomo Metal Mining Co., Ltd.)

2. Graduate student, Graduate School of Kyushu University (present : Institute for Advanced Materials Processing, Tohoku University)

3. Graduate school of Engineering, Kyushu University, Higashi-ku Fukuoka 812-8581

Kinetic behavior of lead removal from liquid copper by slag-metal reaction was investigated at $1200{ }^{\circ} \mathrm{C}$ on a laboratory scale. Various slags composed of $\mathrm{Cu}_{2} \mathrm{O}, \mathrm{Fe}_{2} \mathrm{O}_{3}, \mathrm{~B}_{2} \mathrm{O}_{3}$ and $\mathrm{SiO}_{2}$ were used, For $\mathrm{Cu}_{2} \mathrm{O}-\mathrm{M}_{\mathrm{x}} \mathrm{O}_{\mathrm{y}}(\mathrm{M}=\mathrm{B}$, $\mathrm{Si}, \mathrm{Fe}$ ) binary slags, $\mathrm{B}_{2} \mathrm{O}_{3}$ addition was most effective for the lowering of activity coefficient of $\mathrm{PbO}$ in slag. As a result, larger removal rate of lead from liquid copper was obtained under the experimental condition of higher contents of $\mathrm{B}_{2} \mathrm{O}_{3}$ and oxygen. $\mathrm{SiO}_{2}$ was also an effective slag component for the lead removal, but the reaction rate was retarded by its addition to slags. The kinetic behavior of lead removal by oxidizing slags could be simulated by the reaction model based on the two film theory.

KEY WORDS : Removal of Lead in Liquid Copper, Slag-metal Reaction, Reaction Rate of Oxidation, $\mathrm{B}_{2} \mathrm{O}_{3}$ containing Slag

\section{1. 緒}

資源の有効利用，省エネルギー，環境との調和などの観点から 銅スクラップの乾式精鍊による高純度化に再度関心が向けられ ている1)-3)。銅スクラップ中の混入量が比較的多いと報告されて いる不純物， $\mathrm{Fe} ， \mathrm{Zn}, \mathrm{Sn}, \mathrm{Ni}, \mathrm{Pb}$ などの中で，たとえば，酸素と の親和力が大きい $\mathrm{Fe}, \mathrm{Zn}, \mathrm{Sn}$ は単なる空気吹き付けで容易に酸 化されるが, $\mathrm{Pb}, \mathrm{Ni}$ は酸素との親和力がそれほど大きくなく, 工 業的に要求される低濃度までの酸化除去は非常に困難であるこ とが知られている1)-4)

不純物の酸化生成物をスラグに吸収させ，その活量を低下させ ることが酸化除去に有効であることはよく知られている ${ }^{1)}$ 。しか し, 空気吹きつけの場合に生成するスラグはほぼ純 $\mathrm{Cu}_{2} \mathrm{O}$ で, 不 純物の酸化生成物の活量係数の低下があまり期待できない。 $\mathrm{Pb}$ を 例にとると, その酸化物である $\mathrm{PbO}$ は塩基性であり, $\mathrm{SiO}_{2}$ など の酸性酸化物の添加はスラグ中の活量係数の低下を助長するた め, $\mathrm{Pb}$ の酸化除去に有効である。しかしながら, $\mathrm{Pb}$ 除去に関す るその他の酸性酸化物の影響に関寸る系統的研究は少なく, 速度 論的な観点からの検討に関する報告はほとんどなされていない。 本研究では, 溶銅中の $\mathrm{Pb}$ の除去に有効なスラグ組成および速

* 1999 年 12 月 21 日受付 2000 年 5 月 19 日受理

1. 学生会員 九州大学大学院生 (現 住友金属鉱山 (株) 新居浜研究所)

2. 正会員 九州大学大学院生 (現 東北大学助手 素材工学研究所素材再生プ ロセス研究センター)

3. 九州大学大学院教務員 工学研究科物質プロセス工学専攻

4. 工博 九州大学助教授 大学院工学研究科物質プロセス工学専攻

5. 正会員 工博 九州大学教授 大学院工学研究科物質プロセス工学専攻

[ 著者連絡先 ] FAX 092-632-0434 (九大・森)

キーワード : 溶銅中鉛の酸化除去, スラグーメタル反応, 酸化速度, $\mathrm{B}_{2} \mathrm{O}_{3}$ 含有 スラグ
度論的反応機構の解明を目的に, 酸性酸化物として $\mathrm{SiO}_{2}, \mathrm{~B}_{2} \mathrm{O}_{3}$, $\mathrm{Fe}_{2} \mathrm{O}_{3}$ を選び, 酸化精錬においては不可避である $\mathrm{Cu}_{2} \mathrm{O}$ を含む $\mathrm{Cu}_{2} \mathrm{O}-\mathrm{Fe}_{2} \mathrm{O}_{3}-\mathrm{B}_{2} \mathrm{O}_{3}-\mathrm{SiO}_{2}$ 系スラグを用いて, 溶銅中の $\mathrm{Pb}$ の酸化除 去挙動に及ぼすスラグ組成の影響を調べ, 競合反応モデルによる 速度論的検討を行った。

\section{2. 実 験 方 法}

実験方法は基本的には前報 ${ }^{4)}$ と同じである。表面の酸化物を除 去した約 $200 \mathrm{~g}$ の電気銅を内径 $36 \mathrm{~mm}$ の丸底アルミナるつぼに入 れて炉内に設置し，アルゴン雾囲気中で銅を加熱溶解する。1,200 C に保持した後, $0.1 \%$ \% $\mathrm{Pb}$ を溶銅中に添加し, 石英管で十分攪 挥した後初期メタル分析用試料を石英管で吸引採取する。次に予 備溶製したスラグ試料 $20 \sim 40 \mathrm{~g}$ を入れた銅製のスラグホルダー $(19 \mathrm{~mm} \phi \times 18 \mathrm{~mm} \phi \times 100 \mathrm{~mm})$ を炉上部から挿入し, メタル浴 上で溶解させた後, スラグホルダー底面をメタル浴面に接触させ ることにより，スラグをメタル上に添加する。この時を反応開始 時間として以後, 約 60 分間適当な時間間隔でメタル試料の採取 を行う。最終メタル試料採取後, 鉄線を用いてスラグ試料を採取 し, 分析に供する。採取したメタル試料については, 原子吸光々 度法により $\mathrm{Pb}$ 分析, 不活性ガス融解非分散赤外線吸収法で酸素 分析を行い, スラグ試料については, 原子吸光々度法により $\mathrm{Cu}$, $\mathrm{Fe}, \mathrm{Pb}, \mathrm{Al}, \mathrm{Mg}$ 分析を, 重量法により $\mathrm{SiO}_{2}$ 分析を行い, 残りを $\mathrm{B}_{2} \mathrm{O}_{3}$ とした。用いたスラグ組成, 実験条件を Table 1 に示す。な

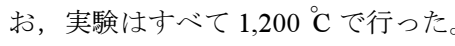

\section{3. 実 験 結 果}

$3 \cdot 1 \mathrm{Cu}_{2} \mathrm{O}-\mathrm{M}_{\mathrm{x}} \mathrm{O}_{\mathrm{y}}(\mathrm{M}=\mathrm{Si}, \mathrm{B}, \mathrm{Fe}) 2$ 元系スラグ

最終メタルおよびスラグの分析結果をTable 2 にまとめて示す。 
Table 1 Initial experimental conditions of slag and metal

\begin{tabular}{l|ccccc|cc|cc}
\hline \hline \multirow{2}{*}{$\begin{array}{l}\text { Run } \\
\text { No. }\end{array}$} & \multicolumn{3}{|c|}{ Initial slag composition(mass\%) } & \multicolumn{2}{c|}{ Weight(g) } & \multicolumn{2}{c}{ Initial } \\
\cline { 2 - 10 } & $\mathrm{Cu} 2 \mathrm{O}$ & $\mathrm{Fe}_{2} \mathrm{O}_{3}$ & $\mathrm{~B}_{2} \mathrm{O}_{3}$ & $\mathrm{SiO}_{2}$ & $\mathrm{Al}_{2} \mathrm{O}_{3}$ & $\mathrm{Slag}$ & Metal & {$[\% \mathrm{~Pb}]$} & {$[\% \mathrm{O}]$} \\
\hline \hline $\mathrm{A}-1$ & 94.3 & - & - & 4.7 & 1.0 & 20 & 200.0 & 0.097 & 0.024 \\
$\mathrm{~A}-2$ & 94.3 & - & - & 4.7 & 1.0 & 40 & 219.7 & 0.090 & 0.024 \\
\hline B-1 & - & - & 100 & - & - & 40 & 226.9 & 0.105 & 0.035 \\
B-2 & 26.5 & - & 73.5 & - & - & 20 & 220.3 & 0.086 & 0.020 \\
B-3 & 49.3 & - & 49.2 & - & 1.5 & 40 & 229.6 & 0.087 & 0.012 \\
B-4 & 91.0 & - & 5.8 & - & 3.2 & 40 & 238.1 & 0.098 & 0.045 \\
\hline C-1 & 93.1 & 6.1 & - & - & 0.8 & 30 & 214.5 & 0.101 & 0.038 \\
C-2 & 61.5 & 38.3 & - & - & 0.2 & 30 & 207.5 & 0.100 & 0.062 \\
\hline D-1 & - & 57.7 & 32.3 & - & 10.0 & 40 & 224.1 & 0.097 & 0.092 \\
D-2 & - & 23.5 & 62.8 & - & 13.7 & 40 & 210.7 & 0.107 & 0.055 \\
D-3 & - & 15.5 & 83.0 & - & 1.5 & 36 & 222.0 & 0.122 & 0.081 \\
D-4 & - & 5.0 & 94.6 & - & 0.4 & 33 & 208.4 & 0.055 & 0.084 \\
\hline E-1 & 10.3 & 4.2 & 84.5 & - & 1.0 & 33 & 209.5 & 0.106 & 0.040 \\
E-2 & 21.0 & 26.3 & 51.8 & - & 0.9 & 30 & 207.2 & 0.131 & 0.051 \\
E-3 & 40.2 & 15.1 & 43.7 & - & 1.0 & 30 & 229.8 & 0.112 & 0.039 \\
\hline F-1 & 30.9 & 21.7 & 34.1 & 10.1 & 3.2 & 30 & 229.9 & 0.112 & 0.027 \\
\hline G-1 & 49.3 & - & 49.2 & - & 1.5 & 17 & 144.0 & 0.090 & 0.054 \\
\hline \hline
\end{tabular}

Table 2 Chemical compositions of final metal and slag, and values of $p_{\mathrm{O}_{2}}, \mathrm{LPb}$ and $\gamma_{\mathrm{PbO}}$ calculated from final conditions.

\begin{tabular}{|c|c|c|c|c|c|c|c|c|c|c|c|c|}
\hline \multirow{2}{*}{$\begin{array}{l}\text { Run } \\
\text { No. }\end{array}$} & \multicolumn{9}{|c|}{ Final metal and slag composition(mass \%) } & \multirow{2}{*}{$p^{1 / 2}{ }_{02}$} & \multirow{2}{*}{$L_{\mathrm{Pb}}$} & \multirow{2}{*}{$\gamma \mathrm{PbO}$} \\
\hline & {$[\% \mathrm{~Pb}]$} & {$[\% \mathrm{O}]$} & $\mathrm{Cu}_{2} \mathrm{O}$ & $\mathrm{Fe}_{2} \mathrm{O}_{3}$ & $\mathrm{~B}_{2} \mathrm{O}_{3}$ & $\mathrm{SiO}_{2}$ & $\mathrm{Al}_{2} \mathrm{O}_{3}$ & $\mathrm{MgO}$ & $\mathrm{PbO}$ & & & \\
\hline A-1 & 0.014 & 0.971 & - & - & - & - & - & - & - & 0.00579 & - & - \\
\hline A-2 & 0.007 & 1.132 & - & - & - & - & - & - & - & 0.00675 & - & - \\
\hline B-1 & 0.077 & 0.040 & 0.63 & - & 98.7 & - & 0.4 & - & 0.23 & 0.00034 & 2.9 & 0.84 \\
\hline B-2 & 0.036 & 0.114 & 19.7 & - & 69.3 & - & 10.2 & - & 0.78 & 0.00092 & 20.1 & 0.29 \\
\hline B-3 & 0.011 & 0.148 & 34.0 & - & 50.6 & - & 14.8 & - & 0.59 & 0.00119 & 50.0 & 0.14 \\
\hline B-4 & 0.003 & 0.843 & 59.3 & - & 29.8 & - & 9.8 & - & 1.12 & 0.00541 & 372 & 0.07 \\
\hline$C-1$ & 0.029 & 1.082 & 68.0 & 29.5 & - & - & 0.8 & - & 0.99 & 0.00645 & 31.6 & 0.90 \\
\hline $\mathrm{C}-2$ & 0.068 & 0.595 & 29.2 & 68.6 & - & - & 1.3 & - & 0.43 & 0.00412 & 5.9 & 2.32 \\
\hline D-1 & 0.065 & 0.092 & - & - & - & - & - & - & - & 0.00074 & - & - \\
\hline D-2 & 0.015 & 0.055 & 11.8 & 22.5 & 49.3 & - & 15.9 & - & 0.50 & 0.00045 & 30.7 & 0.08 \\
\hline D-3 & 0.009 & 0.081 & - & - & - & - & - & - & - & 0.00066 & - & - \\
\hline D-4 & 0.011 & 0.084 & 0.4 & 1.5 & 96.5 & - & 1.5 & - & 0.07 & 0.00068 & 6.0 & 0.82 \\
\hline E-1 & 0.011 & 0.061 & 9.4 & 2.6 & 82.0 & - & 5.7 & - & 0.33 & 0.00050 & 28.2 & 0.12 \\
\hline $\mathrm{E}-2$ & 0.007 & 0.207 & 23.4 & 23.0 & 35.8 & - & 16.8 & - & 0.68 & 0.00162 & 87.5 & 0.09 \\
\hline E-3 & 0.006 & 0.293 & 40.4 & 12.6 & 30.9 & - & 15.1 & - & 0.61 & 0.00223 & 91.6 & 0.13 \\
\hline F-1 & 0.019 & 0.182 & 25.9 & 10.9 & 41.9 & 9.5 & 11.2 & - & 0.59 & 0.00144 & 28.4 & 0.27 \\
\hline G-1 & 0.007 & 0.284 & 27.1 & - & 20.4 & - & 1.8 & 49.3 & 0.80 & 0.00217 & 10.3 & 1.21 \\
\hline
\end{tabular}

In Run A-1,A-2,D-1 and D-3, sound slag samples for chemical analysis were not obtained.

なお，表中の最終スラグ組成の欄が空白のものは健全な最終スラ グが採取できなかったためであり，また， $\mathrm{Al}_{2} \mathrm{O}_{3}$ および $\mathrm{MgO}$ はる つぼからの溶解によるものである。

$\mathrm{Cu}_{2} \mathrm{O}$ に約 $5 \sim 6$ mass \% $の \mathrm{SiO}_{2}(\mathrm{~A}-2), \mathrm{B}_{2} \mathrm{O}_{3}$ (B-4) および $\mathrm{Fe}_{2} \mathrm{O}_{3}$ (C-1) を添加した 2 元系スラグを用いた場合の $\mathrm{Pb}$ および酸素濃度 の経時変化を Fig.1 に示す。なお, 図中の実線は後述のモデルに 基づく計算曲線である。図より $\mathrm{B}_{2} \mathrm{O}_{3}$ を添加した場合の $\mathrm{Pb}$ の除去 が最も良好であり, $\mathrm{SiO}_{2}$ の添加では溶銅中の酸素濃度が増大して いるにもかかわらず， $\mathrm{Pb}$ の除去率は低下している。しかし, $\mathrm{Fe}_{2} \mathrm{O}_{3}$ の添加ではスラグ添加量が $30 \mathrm{~g}$ と少ないことを考慮しても, 他の スラグに比べて $\mathrm{Pb}$ の酸化除去量および酸化速度が著しく低下寸
ることが分かる。それでも, 生成スラグが純 $\mathrm{Cu}_{2} \mathrm{O}$ に近く, 溶銅 中の酸素濃度が 1 mass \% 以上で $\mathrm{Pb}$ の酸化が始まる前報の空気吹 きつけ実験結果 ${ }^{4)}$ と比較すると $\mathrm{Pb}$ の除去には酸性酸化物の添加 が有効であることが分かる。

そこで, $\mathrm{Cu}_{2} \mathrm{O}-\mathrm{B}_{2} \mathrm{O}_{3}$ 系 ( スラグ $\mathrm{B}$ ) における $\mathrm{Pb}$ 除去に及ぼす $\mathrm{B}_{2} \mathrm{O}_{3}$ 濃度の影響を Fig.2 に示す。図より $100 \% \mathrm{~B}_{2} \mathrm{O}_{3}$ スラグでは 酸化に必要な酸素量が不足するため, $\mathrm{Pb}$ の除去量は小さいが, ス ラグ中の $\mathrm{Cu}_{2} \mathrm{O}$ 濃度が高くなるにつれて, 銅中の酸素濃度が高く なり, $\mathrm{Pb}$ の除去が促進されることが分かる。

$3 \cdot 2 \mathrm{Cu}_{2} \mathrm{O}-\mathrm{Fe}_{2} \mathrm{O}_{3}-\mathrm{B}_{2} \mathrm{O}_{3}$ 系スラグ

$\mathrm{Fe}_{2} \mathrm{O}_{3}$ を含むスラグの場合, 実験後の銅中には Fe がほとんど含 


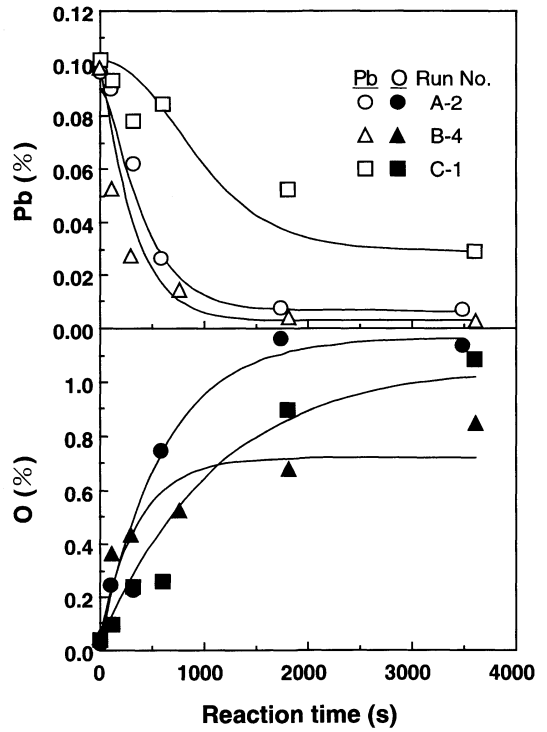

Fig. 1 Effect of $\mathrm{M}_{\mathrm{x}} \mathrm{O}_{\mathrm{y}}$ on the oxidation behavior of lead in liquid copper by $\mathrm{Cu}_{2} \mathrm{O}-\mathrm{M}_{\mathrm{X}} \mathrm{O}_{\mathrm{y}}$ binary slags. (Solid lines are the simulation results)

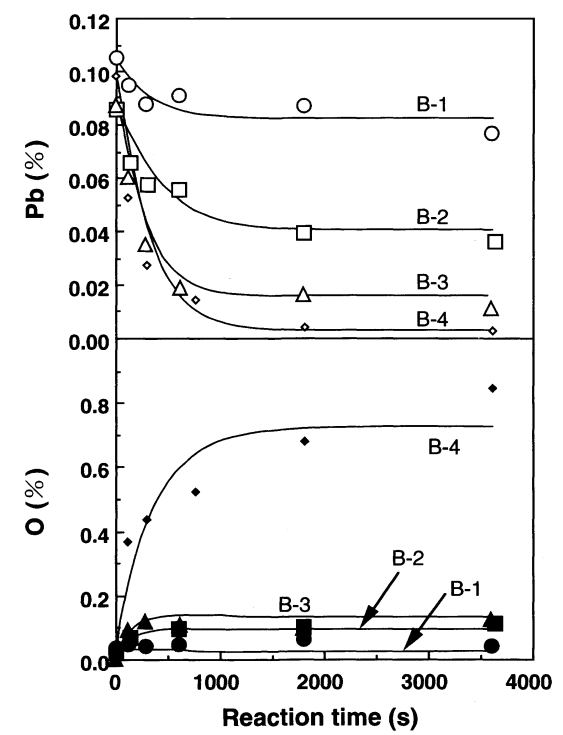

Fig. 2 Effect of $\mathrm{B}_{2} \mathrm{O}_{3}$ content on the oxidation behavior of lead in liquid copper by $\mathrm{Cu}_{2} \mathrm{O}-\mathrm{B}_{2} \mathrm{O}_{3}$ binary slags. (Solid lines are the simulation results)

まれていなかったので添加された $\mathrm{Fe}_{2} \mathrm{O}_{3}$ の一部は次の分解反応 $\left(\mathrm{Fe}_{2} \mathrm{O}_{3}=2 \mathrm{FeO}+\underline{\mathrm{O}}\right)$ により, 溶銅への酸素供給剂として働くもの と考えられる。その際, 分解で生じる酸素の一部は $\mathrm{Cu}_{2} \mathrm{O}$ として スラグに残存するので, $\mathrm{Fe}_{2} \mathrm{O}_{3}-\mathrm{B}_{2} \mathrm{O}_{3} 2$ 元系 ( スラグ D) は実質的に は $\mathrm{Cu}_{2} \mathrm{O}-\mathrm{Fe}_{2} \mathrm{O}_{3}-\mathrm{B}_{2} \mathrm{O}_{3} 3$ 元系 ( スラグ $\mathrm{E}$ ) とみなされる。スラグ $\mathrm{D}$ に よる $\mathrm{Pb}$ 酸化除去挙動を Fig.3に，スラグ $\mathrm{E}$ による結果を Fig.4 に 示す。スラグ $\mathrm{D}$ の場合, $\mathrm{Fe}_{2} \mathrm{O}_{3}$ 濃度の低下によって酸素供給力は 低下寸るにもかかわらず, $\mathrm{Pb}$ は低濃度まで酸化除去されるが, D4 のように $\mathrm{Fe}_{2} \mathrm{O}_{3}$ があまり少なすぎると供給酸素量不足のためか $\mathrm{Pb}$ の酸化量は低下寸ることが分かる。

上記の実験ではいずれの場合にも最終酸素濃度は 0.1 mass \% 以 下と低く, さらに酸素濃度を増大させることで $\mathrm{Pb}$ 除去が促進す ることが期待できる。そこで, $\mathrm{Fe}_{2} \mathrm{O}_{3} / \mathrm{B}_{2} \mathrm{O}_{3}=0.3 \sim 0.5$ と固定し, $\mathrm{Cu}_{2} \mathrm{O}$ を添加した場合, $\mathrm{Cu}_{2} \mathrm{O}$ 添加量の増大とともに溶解酸素濃度 が増加し, $\mathrm{Pb}$ の最終濃度は 2 元系スラグでの 150 mass ppm から 3 元系スラグでは $60 \sim 70$ mass ppm まで低下寸ることが Fig.4 よ り明らかであり, 反応系への酸素の供給が効果的であることが分 かる。

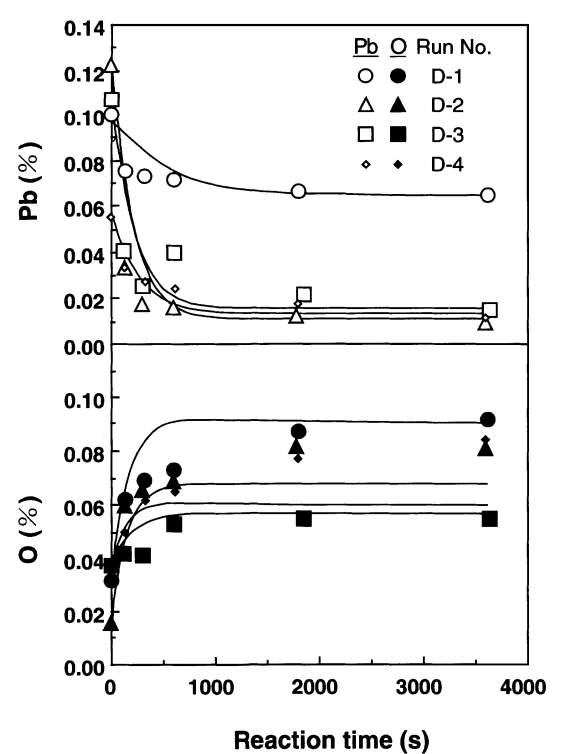

Fig. 3 Effect of $\mathrm{Fe}_{2} \mathrm{O}_{3} / \mathrm{B}_{2} \mathrm{O}_{3}$ ratio on the oxidation behavior of lead in liquid copper by $\mathrm{Cu}_{2} \mathrm{O}-\mathrm{Fe}_{2} \mathrm{O}_{3}-\mathrm{B}_{2} \mathrm{O}_{3}$ ternary slags.

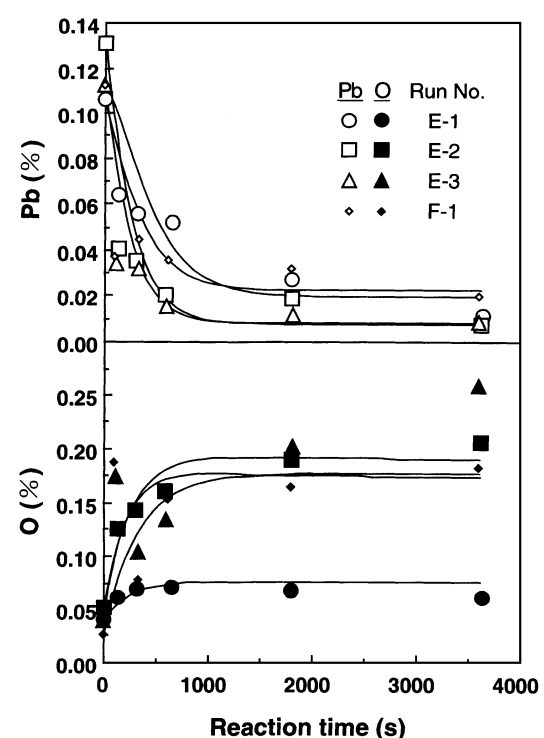

Fig. 4 The oxidation behavior of lead in liquid copper by $\mathrm{Cu}_{2} \mathrm{O}-\mathrm{Fe}_{2} \mathrm{O}_{3}-\mathrm{B}_{2} \mathrm{O}_{3}$ ternary (Slag E) and $\mathrm{Cu}_{2} \mathrm{O}-\mathrm{Fe}_{2} \mathrm{O}_{3}-\mathrm{B}_{2} \mathrm{O}_{3}-\mathrm{SiO}_{2}$ quaternary (Slag F) slags.

\section{$3 \cdot 3 \mathrm{Cu}_{2} \mathrm{O}-\mathrm{Fe}_{2} \mathrm{O}_{3}-\mathrm{B}_{2} \mathrm{O}_{3}-\mathrm{SiO}_{2}$ 系スラグ}

$\mathrm{B}_{2} \mathrm{O}_{3}$ と $\mathrm{SiO}_{2}$ の $\mathrm{Pb}$ 除去に及ぼす効果を比較するために, $\mathrm{Cu}_{2} \mathrm{O}-$ $\mathrm{Fe}_{2} \mathrm{O}_{3}-\mathrm{B}_{2} \mathrm{O}_{3}$ 系スラグの $\mathrm{B}_{2} \mathrm{O}_{3}$ の一部を $\mathrm{SiO}_{2}$ に置換した 4 元系スラ グによる結果を Fig.4に併示した。図より $\mathrm{SiO}_{2}$ との置換により $\mathrm{Pb}$ の酸化速度および除去量はともに低減することが明らかであり, このことより酸性度が強い $\mathrm{B}_{2} \mathrm{O}_{3}$ の方が $\mathrm{SiO}_{2}$ よりも $\mathrm{Pb}$ の除去に 有効と考えられる。

\section{$3 \cdot 4$ るつぼ材の影響}

実験終了時のスラグにはるつぼ材である $\mathrm{Al}_{2} \mathrm{O}_{3}$ のスラグ中への 溶け込みが見られた。同じスラグ (B-3) を用いて $\mathrm{Al}_{2} \mathrm{O}_{3}$ の代わり に $\mathrm{MgO}$ るつぼを用いた実験 (G-1) では, Table 2 に示したように 実験後のスラグ中には 50 mass \% 近くの $\mathrm{MgO}$ の溶け込みがみら れ, $\mathrm{MgO}$ るつぼは $\mathrm{B}_{2} \mathrm{O}_{3}$ 系スラグに対する耐食性は $\mathrm{Al}_{2} \mathrm{O}_{3}$ に比べ て劣ることが分かる。しかし, 初期スラグが同じ B-3 と比較する と, 溶銅中の酸素濃度が高く, その結果, $\mathrm{Pb}$ はより低濃度まで除 去されているが, 分配值や $\mathrm{PbO}$ の活量係数などを考慮すれば, $\mathrm{Pb}$ の除去には B スラグの方が有効と考えられる。 


\section{4. 考察}

\section{$4 \cdot 1$ 分配値}

本実験条件下ではスラグー溶銅間において下記の 4 つの反応が 同時に進行すると考えられる。

$\mathrm{Pb}(\mathrm{l})+1 / 2 \mathrm{O}_{2}=\mathrm{PbO}(\mathrm{l})$

$\ln K_{\mathrm{Pb}}=21791 / T-8.20^{9)}$

$\mathrm{Cu}(\mathrm{l})+1 / 4 \mathrm{O}_{2}=\mathrm{CuO}_{0.5}$ (1)

$\ln K_{\mathrm{Cu}}=7141 / T-2.37^{9)}$

$\mathrm{FeO}(\mathrm{l})+1 / 4 \mathrm{O}_{2}=\mathrm{FeO}_{1.5}(\mathrm{~S})$

$\ln \mathrm{K}_{\mathrm{Fe}}=19823 / T-9.54^{9)}$

$1 / 2 \mathrm{O}_{2}=\underline{\mathrm{O}}(\operatorname{mass} \%)$

$\ln K_{\mathrm{O}}=10266 / T-2.24^{9)}$

本実験の多くでは溶銅中の $\mathrm{Pb}$ 濃度は実験終了時にはほぼ一定值 を示しており，この時点ではスラグーメタル間はほぼ平衡状態に 近いものと考えられる。そこで, $\mathrm{B}_{2} \mathrm{O}_{3}$ を含むスラグの熱力学的性 質に関する報告は非常に少ないので, 本実験結果に基づき分配值 やスラグ中の $\mathrm{PbO}$ の活量係数の推定を試みる。

反応 (1) よりスラグー溶銅間の $\mathrm{Pb}$ の平衡分配值 $L_{\mathrm{Pb}}$ は式 (5) で 与えられる。

$$
\begin{aligned}
L_{\mathrm{Pb}} & =(\% \mathrm{~Pb}) /[\% \mathrm{~Pb}] \\
& =K_{\mathrm{Pb}}\left(n_{\mathrm{T}}\right) \gamma_{\mathrm{Pb}} p_{\mathrm{O}_{2}}^{1 / 2} /\left[n_{\mathrm{T}}\right] \gamma_{\mathrm{PbO}}
\end{aligned}
$$

ここで, $\left(n_{\mathrm{T}}\right),\left[n_{\mathrm{T}}\right]$ はそれぞれスラグおよびメタル $100 \mathrm{~g}$ 中の総 モル数で, $\gamma$ はラウール基準での活量係数を表す。酸素分圧を $p_{\mathrm{O}_{2}}$ $=P_{\mathrm{O}_{2}} / P^{\circ}$ で定義すると, 溶銅中の酸素濃度 (モル分率で $\mathrm{X}_{\mathrm{O}}$ ) と酸 素分圧, 活量係数 $\left(\gamma_{O}\right)$ との間には次の関係が成り立つ。

$$
p_{\mathrm{O}_{2}}^{1 / 2}=\gamma_{\mathrm{O}} \mathrm{X}_{\mathrm{O}}
$$

溶銅中の酸素の無限希薄溶液中での活量係数 $\left(\ln \gamma_{O}^{0}=4.734-\right.$ $\left.9262 / T^{5)}\right)$ およひ酸素の相互作用母係数 $\left(\varepsilon_{\mathrm{O}}^{\mathrm{O}}=11.5-27660 / T^{5)}\right)$ を 用いて溶銅中の酸素濃度から計算した酸素分圧と $L_{\mathrm{Pb}}$ の関係を Fig.5 に示す。図より $\mathrm{Fe}_{2} \mathrm{O}_{3}$ の単独添加では $L_{\mathrm{Pb}}$ はそれほど大きく ないが, $\mathrm{B}_{2} \mathrm{O}_{3}$ と $\mathrm{Fe}_{2} \mathrm{O}_{3}$ が共存する場合, $\mathrm{Pb}$ の分配值が増大寸る ことが分かる。比較のために図には日野ら ${ }^{3)}$ や Takeda ら ${ }^{6)}$ の $\mathrm{FeO}_{n}$ $\mathrm{CaO}-\mathrm{SiO}_{2}$ 系スラグによる結果および $\mathrm{Cu}_{2} \mathrm{O}-\mathrm{SiO}_{2}$ スラグに関する $\mathrm{R}$. P. Das $ら^{7)}$ による結果から算出した值を併示したが, 本実験結果 はこれらの值より大きな分配值を示しており, 特に $\mathrm{Pb}$ の除去に 対寸る $\mathrm{B}_{2} \mathrm{O}_{3}$ の有効性が明らかである。

$\mathrm{B}_{2} \mathrm{O}_{3}$ 系スラグに関するデータが非常に乏しいので, 最終メタ ル, スラグの分析值に基づき式 (4) 〜 (6) から推算された $p_{\mathrm{O}_{2}}, L_{\mathrm{Pb}}$ および $\gamma_{\mathrm{PbO}}$ の值を Table 2 に併記した。なお, 計算ではメタル $100 \mathrm{~g}$ 中のモル数は $\left[n_{\mathrm{T}}\right] \doteqdot 100 / M_{\mathrm{Cu}}=1.57$ とし, $\mathrm{Pb}$ の活量係数 には文献值 $\gamma_{\mathrm{Pb}}=5.5^{3)}$ を用いた。

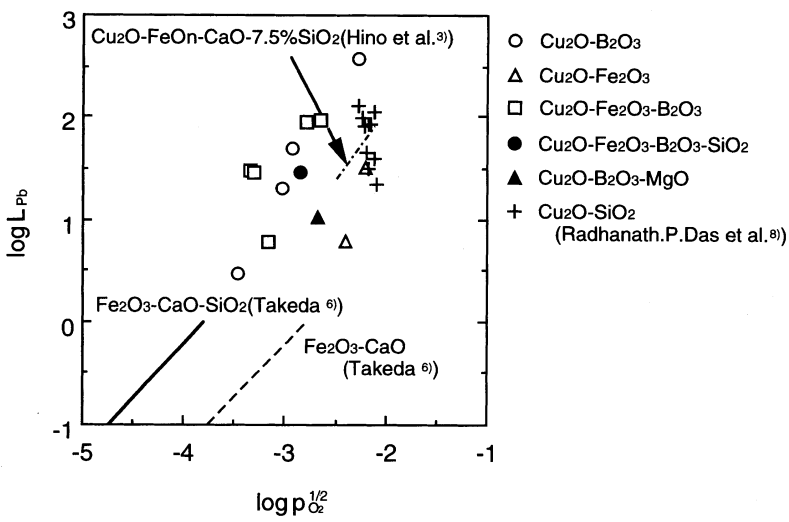

\begin{tabular}{|c|c|c|}
\hline Slag & $\gamma_{\mathrm{PbO}}$ & Reference \\
\hline $\mathrm{B}_{2} \mathrm{O}_{3}$-containing Slag & $0.07 \sim 0.84$ & Present Work \\
\hline $\mathrm{CaO}-\mathrm{Fe}_{2} \mathrm{O}_{3}$ & 3.2 & Takeda et al. ${ }^{6}$ \\
\hline $\mathrm{CaO}-\mathrm{Fe}_{2} \mathrm{O}_{3}-\mathrm{SiO} 2$ & 0.4 & \\
\hline $\mathrm{Cu}_{2} \mathrm{O}-\mathrm{SiO}_{2}$ & $0.08 \sim 0.9$ & Das et al. ${ }^{8)}$ \\
\hline $\mathrm{Cu}_{2} \mathrm{O}-\mathrm{CaO}-\mathrm{FeO}-\mathrm{SiO}_{2}$ & $0.15 \sim 0.6$ & Hino et al. ${ }^{3)}$ \\
\hline
\end{tabular}

Fig. 5 Relation between distribution ratio of $\mathrm{Pb}$ and oxygen potential
Table 3 Comparison of activity coefficients of $\mathrm{PbO}$ in various slags.

前報の空気吹きつけ実験 ${ }^{4)} や \mathrm{C}$ スラグでの結果と比較すると $\mathrm{B}_{2} \mathrm{O}_{3}$ を含むスラグでの $\gamma_{\mathrm{PbO}}$ の低下は明瞭である。これは酸性成 分の添加効果と考えられるが, 高濃度の $\mathrm{B}_{2} \mathrm{O}_{3}$ を含む場合にむし ろ $\gamma_{\mathrm{PbO}}$ が増大している。このような結果が生じた理由は現在不明 であるが, $\mathrm{B}_{2} \mathrm{O}_{3}$ を含むスラグ系は高 $\mathrm{B}_{2} \mathrm{O}_{3}$ 濃度域で 2 液相分離の 傾向を示寸ものが多い。この結果, 酸性成分の多いにもかかわら ず, $\gamma_{\mathrm{PbO}}$ が増大したものと推定される。

一方, 銅精錬スラグでの $\mathrm{PbO}$ の活量係数に関していくつかの報 告がなされている。本実験結果と他のスラグ系についての文献值

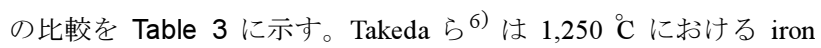
silicate スラグと溶銅間の $\mathrm{Pb}$ の平衡分配值を測定し, $\gamma_{\mathrm{PbO}}=0.4$ と いう值を得ている。さらに, 日野ら ${ }^{3)}$ の結果によれば, $\mathrm{SiO}_{2}$ 含有 量の高いスラグほど $\gamma_{\mathrm{PbO}}$ が低下寸る傾向が見られる。本実験で用 いたスラグ中での $\mathrm{PbO}$ の活量係数は従来のスラグ系に比べて小さ く, 鉛の酸化除去に有効であることが分かる。

\section{$4 \cdot 2$ 反応速度の解析}

上記の4つの反応はいずれも異相間の物質移動反応であるので, 2 重境膜説によれば 1) メタル相内の物質移動過程, 2) 界面での酸 化・還元反応，3）スラグ相内の物質移動過程を伴う。

一般に, 高温でのスラグーメタル間の物質交換反応は進行が速 く, 反応界面ではほぼ平衡状態に近いと考えられる。その場合, 総括反応速度はスラグおよびメタル中の物質移動に支配され, 各 成分の濃度の時間変化は以下のように与えられる。

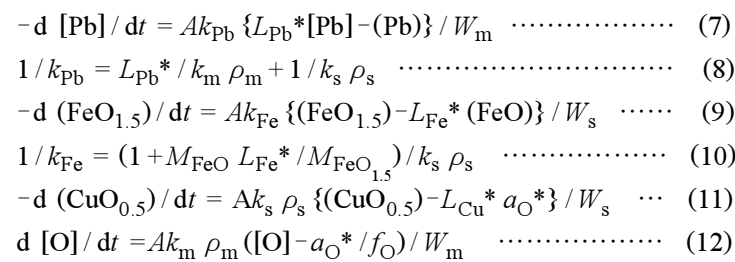

ここで, $[\mathrm{X}]$ および $(\mathrm{X})$ は成分 $\mathrm{X}$ のメタル及びスラグ中での濃 度 (mass \%) を表わす。さらに, 式中の $k_{\mathrm{i}}$ は成分 $\mathrm{i}(\mathrm{i}=\mathrm{Pb}, \mathrm{Fe})$ の 総括物質移動係数 $(\mathrm{cm} / \mathrm{s}), W$ は重量 $(\mathrm{g}), \rho$ は密度 $\left(\mathrm{g} / \mathrm{cm}^{3}\right), M$ は分子量, $L$ は平衡分配值, $k_{\mathrm{m}}, k_{\mathrm{s}}$ はメタル中およびスラグ中の 物質移動係数 $(\mathrm{cm} / \mathrm{s}), a_{\mathrm{O}} * ， f_{\mathrm{O}}$ は mass \% を用いた場合の Henry 基準での酸素の活量および活量係数を表わす。添字について, m はメタル， $\mathrm{s}$ はスラグ，*は界面での量を意味する。また，溶銅中 への鉄の溶解はないものとした。

反応系が物質移動律速の場合, 界面においては各反応の平衡酸 素分圧は共通である。したがって, 各成分の界面での平衡分配值 $L$ および見かけの平衡定数 $B$ は次の関係式で与えられる。

$$
\begin{aligned}
& L_{\mathrm{Pb}} *=B_{\mathrm{Pb}} a_{\mathrm{O}}^{*}: B_{\mathrm{Pb}}=K_{\mathrm{Pb}}\left(n_{\mathrm{T}}\right) \gamma_{\mathrm{Pb}} / K_{\mathrm{O}}\left[n_{\mathrm{T}}\right] \gamma_{\mathrm{PbO}} \cdots \cdots \\
& L_{\mathrm{Fe}}{ }^{*}=B_{\mathrm{Fe}}\left(a_{\mathrm{O}}\right)^{1 / 2}: B_{\mathrm{Fe}}=K_{\mathrm{Fe}} M_{\mathrm{FeO}} \gamma_{1.5} \gamma_{\mathrm{FeO}} /\left(K_{\mathrm{O}}\right)^{1 / 2} M_{\mathrm{FeO}} \gamma_{\mathrm{FeO}}
\end{aligned}
$$


Table 4 Values of parameters used in the simulation

\begin{tabular}{|c|c|c|c|c|c|}
\hline \multirow{2}{*}{$\begin{array}{l}\text { Run } \\
\text { No. }\end{array}$} & $\mathrm{km} \rho_{\mathrm{m}}$ & ks $\rho \mathrm{s}$ & \multirow{2}{*}{$\mathrm{BPb}$} & \multirow{2}{*}{$\mathrm{BFe}$} & \multirow{2}{*}{$\mathrm{LC}_{\mathrm{u}}$} \\
\hline & \multicolumn{2}{|c|}{$\left(\mathrm{g} / \mathrm{cm}^{2} \mathrm{~s}\right)$} & & & \\
\hline A-1 & 0.08 & 0.005 & 450 & - & 90 \\
\hline A-2 & 0.08 & 0.005 & 150 & - & 90 \\
\hline B-1 & 0.08 & 0.010 & 2500 & - & 10 \\
\hline B-2 & 0.08 & 0.008 & 800 & - & 300 \\
\hline B-3 & 0.11 & 0.009 & 1200 & - & 280 \\
\hline B-4 & 0.08 & 0.006 & 600 & - & 130 \\
\hline C-1 & 0.10 & 0.002 & 50 & 80 & 90 \\
\hline $\mathrm{C}-2$ & 0.08 & 0.0016 & 30 & 80 & 120 \\
\hline D-1 & 0.12 & 0.008 & 380 & 55 & 90 \\
\hline D-2 & 0.12 & 0.012 & 10000 & 50 & 90 \\
\hline D-3 & 0.12 & 0.016 & 17000 & 40 & 20 \\
\hline D-4 & 0.08 & 0.014 & 8000 & 30 & 10 \\
\hline E-1 & 0.10 & 0.006 & 5000 & 150 & 120 \\
\hline E-2 & 0.10 & 0.007 & 3500 & 150 & 80 \\
\hline E-3 & 0.12 & 0.007 & 4000 & 150 & 180 \\
\hline F-1 & 0.12 & 0.004 & 1500 & 200 & 140 \\
\hline G-1 & 0.15 & 0.0025 & 1000 & - & 80 \\
\hline
\end{tabular}

(15)

さらに, 界面での酸素の供給量と消費量が等しいので, 以下の ような酸素のマスバランスの関係式が成り立つ。

$$
\frac{W_{\mathrm{m}} \mathrm{d}[\mathrm{Pb}]}{M_{\mathrm{Pb}} \mathrm{d} t}=\frac{W_{\mathrm{m}} \mathrm{d}[\mathrm{O}]}{M_{\mathrm{O}} \mathrm{d} t}+\frac{W_{\mathrm{s}} \mathrm{d}(\mathrm{Cu})}{2 M_{\mathrm{Cu}} \mathrm{d} t}+\frac{W_{\mathrm{s}} \mathrm{d}\left(\mathrm{FeO}_{1.5}\right)}{2 M_{\mathrm{FeO}_{1.5}} \mathrm{~d} t}
$$

式 (7) 〜 (15) に含まれる速度パラメータ $\left(k_{\mathrm{m}} \rho_{\mathrm{m}}, k_{\mathrm{s}} \rho_{\mathrm{s}}\right)$ や熱力学 データ $\left(B_{\mathrm{Pb}}, B_{\mathrm{Fe}}, L_{\mathrm{Cu}}, f_{\mathrm{O}}\right)$ が既知であれば, これらの值を式 (16) に代入することで, 各スラグおよびメタル組成に対応する反応界 面での酸素活量の值が求まり, 微少時間 $\mathrm{d} t$ での各成分の濃度変化 が計算できる。 $\mathrm{B}_{2} \mathrm{O}_{3}$ を含むスラグに関するデータはほとんどない ので, 計算では $k_{\mathrm{m}} \rho_{\mathrm{m}}, k_{\mathrm{s}} \rho_{\mathrm{s}}, B_{\mathrm{Pb}}, B_{\mathrm{Fe}}, L_{\mathrm{Cu}}$ をパラメータとし, 実測結果にできるだけ一致するようにこれらの值を定めた。なお, 計算の簡略化のために反応の進行中にパラメータの值は変化しな いものとした. 決定したパラメータの值を Table 4 に示す。Fig.1 〜 4 中実線はこのようにして計算した結果である。

\section{$4 \cdot 3$ パラメータの検討}

$k_{\mathrm{m}} \rho_{\mathrm{m}}$ について, 柴田ら ${ }^{4)}$ は溶銅中の $k_{\mathrm{m}} \rho_{\mathrm{m}}$ の值を $0.1 \mathrm{~g} / \mathrm{cm}^{2} \mathrm{~s}$ と推定しており, 本解析における $k_{\mathrm{m}} \rho_{\mathrm{m}}$ の值は $0.08 \sim 0.15 \mathrm{~g} / \mathrm{cm}^{2} \mathrm{~s}$ であり, 推定值に近い值が得られた。 $k_{\mathrm{s}} \rho_{\mathrm{s}}$ の值は $\mathrm{Cu}_{2} \mathrm{O}-\mathrm{Fe}_{2} \mathrm{O}_{3}-$ $\mathrm{B}_{2} \mathrm{O}_{3}-\mathrm{SiO}_{2}$ 系スラグにおけるデータがなく, 柴田ら ${ }^{4)}$ は $\mathrm{Cu}_{2} \mathrm{O}$ 系 スラグでの值を比較的粘度の低い $\mathrm{CaO}-\mathrm{SiO}_{2}-\mathrm{CaF}_{2}$ 系製鋼スラグの 值を参考に $0.01 \mathrm{~g} / \mathrm{cm}^{2} \mathrm{~s}$ と推定している。 $\mathrm{B}_{2} \mathrm{O}_{3}$ を $\mathrm{SiO}_{2}$ で置換し た場合 ${ }^{10)}$ あるいは $\mathrm{Fe}_{2} \mathrm{O}_{3}$ や $\mathrm{MgO}$ が多く, 融点の高いスラグでは,
粘度は高くなる傾向がある。このようなスラグを用いた場合, $k_{\mathrm{s}} \rho_{\mathrm{s}}$ の值が低下し, 律速過程に対するスラグ中の物質移動の寄与が大 きくなることを暗示している。なお, 計算に際してパラメータの 值は一定と仮定したが, 反応時にスラグ組成が大きく変化する場 合には, パラメータの組成依存性についても今後検討が必要であ る。

$\mathrm{Pb}$ 酸化反応の見かけの平衡定数に相当する $B_{\mathrm{Pb}}$ について, ほぼ 純 $\mathrm{Cu}_{2} \mathrm{O}$ スラグが生成した前報 ${ }^{4)}$ の空気吹きつけ実験での $B_{\mathrm{Pb}}$ 值 は 10 程度であった結果と比べると, $\mathrm{B}_{2} \mathrm{O}_{3}$ や $\mathrm{Fe}_{2} \mathrm{O}_{3}$ を含むスラグ では $B_{\mathrm{Pb}}$ 值は 2 桁位大きな值となっており, この点からも $\mathrm{B}_{2} \mathrm{O}_{3}$ 添 加の有効性が明白である。さらに, B 系スラグと $\mathrm{D}$ および $\mathrm{E}$ 系ス ラグとの比較より $\mathrm{B}_{2} \mathrm{O}_{3}$ の単独添加より $\mathrm{Fe}_{2} \mathrm{O}_{3}$ が共存する方がよ り有効であることが分かる。

\section{5. 結言}

$\mathrm{Cu}_{2} \mathrm{O}-\mathrm{Fe}_{2} \mathrm{O}_{3}-\mathrm{B}_{2} \mathrm{O}_{3}-\mathrm{SiO}_{2}$ 系スラグによる溶銅からの $\mathrm{Pb}$ の除去挙 動を調べ, 各スラグ組成の $\mathrm{Pb}$ 除去能の評価並びに反応速度解析 モデルの構築を行った。得られた結果は以下の通りである。

(1) $\mathrm{Cu}_{2} \mathrm{O}-\mathrm{MxOy}(\mathrm{M}=\mathrm{Si}, \mathrm{B}, \mathrm{Fe}) 2$ 元系スラグでは $\mathrm{B}_{2} \mathrm{O}_{3}$ の添 加が $\mathrm{PbO}$ の活量係数の低下に最も効果的であった。

(2) $\mathrm{Fe}_{2} \mathrm{O}_{3}-\mathrm{B}_{2} \mathrm{O}_{3} 2$ 元系スラグでは $\mathrm{Fe}_{2} \mathrm{O}_{3}$ 濃度が低い方がスラグ の酸性度が高く $\mathrm{Pb}$ は除去されやすかった。さらにスラグに $\mathrm{Cu}_{2} \mathrm{O}$ を加え系の酸素ポテンシャルを増大させると, $[\mathrm{O}]=0.2 \sim 0.3 \%$ で $[\mathrm{Pb}]=60 \sim 70$ mass ppm 程度まで除去できた。

（3）強酸性酸化物である $\mathrm{B}_{2} \mathrm{O}_{3}$ と $\mathrm{SiO}_{2}$ では, $\mathrm{B}_{2} \mathrm{O}_{3}$ の方が活量 係数の低下および反応速度の観点からも $\mathrm{Pb}$ の除去に有効であっ た。

（4） 2 重境膜説に基づき構築した速度解析モデルは実験結果を 良好に再現できることから, 本実験条件内では脱 $\mathrm{Pb}$ は物質移動 律速と考えられる。

終わりに, (株) 神戸製鋼所および日鉱金属 (株)より供試材の提 供を受けたことを記し，謝意を表す。

\section{引用文 献}

1) 大隅研治, 他 : 伸銅技術研究誌, vol. 34, p. $201-205$, (1995)

2) Fujisawa, T., Alvear, G. R. F., Shinpo, Y. and Yamauchi, Ch : Proceedings of the Tokyo Symposium on Recycling and Treatment of Metals, ed. by Nakamura, T. and Maeda, M., Tokyo, p. $15-21$, (1997)

3）日野順三・板垣乙未生 ·矢澤 涁 : 資源と素材, Vol. 105, p. 315-320, (1989)

4) 柴田悦郎 - 山本恵介 - 中島邦彦・森 克巳 : 資源と素材, Vol. 115, p. 455-459, (1999)

5) Stolarczyk, J. E., Cibula , A., Gregory, P. and Ruddle, R.W. : J. Inst. Metals, Vol.86, p. $49-58,(1957-1958)$

6) Takeda, Y., Ishiwata, S. and Yazawa, A. : Trans. Japan Inst. Metals, Vol. 24, p. $518-$ $528,(1983)$

7) 大石敏雄 - 小野勝敏 : 日本金属学会誌, Vol.25, p. 291-299, (1986)

8) Das, R. P. and Healy, G. W. : Metall. Trans. B, Vol. 7B, p. 529-536, (1976)

9) Turkdogan, E. T. : Physical Chemistry of High Temperature Technology, ACADEMIC PRESS, INC., New York, p. 5-210, (1980)

10) Nakashima, K., Kawagoe, T., Ookado, T. and Mori, K. : 5th Intern. Conf. on Molten Slags, Fluxes and Salt, p. $215-221$, (1997) 